\title{
THE ANALYSIS OF THE RELATIONSHIP BETWEEN THE LEVEL OF SOCIO-ECONOMIC DEVELOPMENT, MORTALITY AND LIFE EXPECTANCY
}

The purpose and objectives of the study. The main purpose of the study is to assess the relationship between the level of socio-economic development and mortality and life expectancy. To achieve this goal, it is necessary to identify the main factors affecting the age and sex structure of the population and to determine the mechanism of the impact of these factors on mortality and life expectancy.

Research method and methodology. Comparative analysis, logical-systematic approach, comparison and generalization, analysis and synthesis, economic and statistical methods were used in the research work.

Scientific novelty of the research is based on the relationship between the level of socio-economic development and mortality and life expectancy, as well as the factors determining the age-sex structure of the population, the mechanism of birth, death and migration.

Results. The study analyzes the relationship between the level of socio-economic development and birth and life expectancy based on statistical indicators of Azerbaijan, Turkey, Georgia, Russia and Iran using the FIML strategy. The study found that the age-sex structure of the population is formed as a result of long-term historical changes in the level of births, deaths and migration and the evolution of these processes. Research shows that each of the factors, such as birth and death, more or less affects the age-sex structure of the population.

Conclusions. Research shows that there is a correlation between socio-economic development and mortality and life expectancy. Thus, the full provision of the population with all services in the social sphere, including health, will ultimately reduce mortality and increase life expectancy. At the same time, GDP per capita contributes to the reduction of the maternal mortality rate and the increase in life expectancy by ensuring the material development of the population.

Key words: socio-economic development, human development, economic growth, health development, living standards, life expectancy.

JEL Classification: J11 - Demographic Trends, Macroeconomic Effects, and Forecasts.

\section{Sabina CUMAZADA,}

Postgraduate Student

Institute of Economics of the

Azerbaijan National Academy

of Sciences,

Lecturer at the Management

Department

Azerbaijan Tourism and Management University

sebine.yusifova52@gmail.com

orcid.org/0000-0001-5962-7674

\section{Introduction}

Human development is one of the main factors characterizing the sustainable socio-economic development of any state. The concept of human development, introduced by UN experts in 1990, emphasizes that the main goal of sustainable development is the well-being of the population. Along with all this, in terms of ensuring socio-economic development, improving the welfare of the population is the main goal of the state. All this shows that socio-economic development and human development are interrelated.

Demographic aspects of human development are based on population health, life expectancy, as well as population aging, reproductive health, fertility and other issues. Ensuring sustainable human development requires, above all, the proper organization of education and medical services in the country.

In addition to the above, one of the main indicators of human development is the provision of decent living standards. As a logical consequence of socio-economic development, the welfare of the population is determined by the efficient use of labor resources, the level of employment, income, productivity, working conditions and other factors, as well as the effective distribution of government revenues.

In terms of demographic development, the sustainability of human development means the optimal growth of the population, as 
well as the optimal rate of reproduction. This is an indication that the rapid growth of the population, as well as the steady decline, hinders sustainable development. The high rate of population growth observed in the world today is characterized by an effective increase in environmental impact and an increase in the general needs of the people, which ultimately has a significant impact on economic backwardness, social instability and poverty. At the same time, in many highly developed countries, a sharp decline in population and the rapid development of the aging process result in a reduction in labor resources. Thus, at the national and global levels, sustainable human development, combined with social, demographic and economic development, constitutes a complex system of interactions (Arland, Philipov, 2007).

Demographic factors in socio-economic development. The impact of demographic factors on socioeconomic development has long been the subject of discussion by social scientists. Thus, the discussions on the degree of impact of demographic factors on socio-economic development were carried out in three main directions (Birdsall, Kelley, Sinding, 2017):

- population growth accelerates socio-economic development;

- population growth hinders socio-economic development;

- there is no correlation between population growth and socio-economic development.

There has been considerable discussion around these three hypotheses, and although some evidence has been presented for the validity of each hypothesis, it has been argued that demographic factors (population growth, age, etc.) have a profound effect on socio-economic development.

The rules of behavior of the population and their economic needs differ at different stages of life. Thus, any change in the age-sex structure of the population can significantly affect the overall economic activity of the state. It is clear that while young people and children are investing in education and health, the middle-aged population tends to save. The elderly need medical services and social security, as well as pensions. In this case, countries with a large population of young people and children spend most of their resources to meet the needs of the contingent. This will lead to low economic growth in those countries. At the same time, if the share of the elderly in the country is high, the age structure will have a slowdown in the socio-economic development of the country. The working-age population above and below represents a non-productive labor force, and the maintenance of this class requires higher resources. This, in turn, slows down the growth rate of socio-economic development (Keifits, 2015).

The opposite of the above (high proportion of the able-bodied population) not only leads to a rapid increase in socio-economic development, but also creates a "demographic dividend" (Bloom, 2019).

In economically rapidly developing countries, the process of "demographic transition" is over. This process is characterized by a decline in mortality and fertility rates from high to low. In the early stages of the demographic transition, the population in the 0-14 age group decreases during the decline in birth rates. During this period, the labor force (age group 15-64) is growing at a higher rate than the protected population groups (age groups $0-14$ and $65+$ ) and the demographic burden is declining, which provides resources for investment in economic development and social security. The income of the population is growing faster (Bongaarts, 2009).

The impact of the above-mentioned dividend on the country can cover a period of more than fifty years (Keifits, 2015). It is clear that the low birth rate leads to a reduction in the labor force. A decrease in mortality and a corresponding increase in life expectancy leads to an increase in the number of older generations and an aging population. Taking into account such changes in age structures, the growth rate of per capita income is also declining. This shows that the dividend received earlier has the opposite significance. At the same time, on the other hand, there is a basis for the state to receive a second demographic dividend. One of the main tasks for the able-bodied population, which includes the upper age groups, is to meet their needs after retirement. Thus, this contingent, which does not have full confidence that it will be provided by the family or the state as it approaches retirement age, has a strong incentive to accumulate financial assets. As a result, the amount of national income increases, regardless of where the assets are accumulated.

The study found that the age-sex structure of the population is formed as a result of long-term historical changes in the level of births, deaths and migration, the evolution of these processes, as well as demographic disasters. The main factors that shape the age-sex structure of the population are birth, death and population migration. Each of these factors has the potential to more or less affect the sex-age structure of the population. 


\section{Theoretical framework and major hypotheses}

The suspicions based on both hypothetical and observational comes about recommend that the anticipated changes within the life anticipation at birth as an marker for past, display, and future flow of mortality levels basically were and will be beneath noteworthy influence of the changes within the financial improvement in these nations and particularly with progressing of the living standard and wellbeing conditions of their individuals. In this respect (Shkolnikov et al., 2011: 428) indicated that "The prolongation of life into ancient and oldest-old ages changes the conventional adjust between the diverse stages of the life cycle and has large-scale financial results that will be tended to completely different ways." The current consider is conducted to check whether financial improvement through its foundation factors (GDP per capita and newborn child mortality rate) have pertinent impact on life hope at birth (Andreev, Biryukov, Shaburov, 1994).

Salary impacts the condition of people's lives and could be a primary financial determinant of wellbeing (Bayati et al., 2013). Several studies considered wage as one of the most determinants of wellbeing (Bayati et al., 2013). The national living measures had a coordinate and positive affect on the statistic changes (direct effect of pay on mortality or to the life hope). The next living standard raises utilization goals and cultivates the development and the improvement. The national level of financial improvement works on the nation's statistic alter by means of the middle of the road factors as mortality and life hope at birth, i. e., expanding life span and progressing the life anticipation of all ages and decreasing the mortality dangers in all age bunches.

The rich/poor isolate is well known to demographers. It brings us back to commonplace designs that are watched in statistic marvels and where the hypothesis of the "second statistic transition" clarifies the forms (Bloom, 2019). Social orders where the basic handle is in an afterward stage create less financial development and advancement. But the timing of the decay in newborn child mortality is additionally connected to a broader issue, a pivotal one within the hypothetical writing on the connection between life anticipation and GDP: the primary statistic move (Felice, Andreu, Ippoliti, 2016). In financial matters, the bound together development hypothesis holds that the statistic move plays a significant part in starting the move from stagnation to development (Felice et al., 2016: 814): "The thought is that with the statistic move, higher life anticipation leads to lower ripeness and lower populace development, and hence to higher returns of human capital ventures to those living longer". In turn, lower ripeness and higher human capital both contribute to the rise of GDP per capita. Be that as it may, the roots for the theoretical system bring us once more back to the method of the primary statistic move. Regularly, amid the middle of the road stage of the statistic move when the ripeness rate begins to fall, there are less subordinate children who need to be upheld. In that period, the number of working age individuals develops moderately quicker than the number of children and the share of ancient subordinate individuals has not however expanded. As Artisan and Lee (2012) have clarified the concept of moment statistic profit and its associations with a moo ripeness as a statistic figure; in any case, they have underlined that consistent and proceeding enhancement in grown-up mortality are moreover critical, as is the rising extent of the populace at the more seasoned ages. In this way, amid this stage, more assets for venture in financial improvement and family welfare are accessible, and with all other things being rise to, per capita wage develops quicker. Among a number of potential variables, the center of the investigate is on the part of GDP per capita (Bongaarts, 2009). Within the long run, the slant in financial development, as measured by GDP per capita, is exceptionally likely to be related with the drift in mortality reduction, which is the most component captured by numerous of the stochastic mortality models (Ediev, 2011).

One of the prior benchmark thinks about of the income-health relationship is Preston (1975) who compared diverse countries' life hope and per capita pay for distinctive benchmark a long time (1900, 1930, and 1960) and proposed the "Preston curve" a non-linear and concave experimental relationship between the two (Stengos, Thompson, Wu, 2008: 4). The concave Preston bend has given the method of reasoning for much of the observational work that has taken after. In any case, concurring to Stengos et al. (2008), basic health-per capita salary connections may endure from endogeneity, particularly when it comes to nations on the level parcel of the Preston bend, where wellbeing has come to such a progressed arrange where extra advancements coming from salary development cannot be accomplished. In that case, it would be the turn around affect from wellbeing to salary that would be vital. Around the world information on life anticipation does show up to be emphatically related with financial advancement and business. Enhancements in financial conditions are an critical constrain behind mortality decay. 
Sickles and Taubman (1997) appeared prove that life hope increments as a nation moves forward its standard of living. Looking into the hypothetical center and experimental work of Preston in 1976 on this point, Sickles and Taubman (1997) appeared that the information unequivocally recommend that life span is an financial great, prove that life hope increments as a nation makes strides its standard of living long has been recognized since the higher pay regularly related with advancement makes conceivable in portion the utilization of merchandise and administrations that make strides wellbeing. A number of cross-country ponders have found a positive impact of life hope, or a negative impact of mortality on pay per capita, but the wrangle about is still progressing. The relationship between wellbeing and GDP for 13 Organization for Financial Participation and Advancement (OECD) nations over the final two centuries uncovered that GDP per capita and add up to GDP have a critical affect on life hope for most nations (Niu, Melenberg, 2013), and thus, it was taken after by lower mortality rates. A causal clarification of the flow by age and cohort effects and financial conditions may be a promising line of mortality inquire about. As a great illustration, Ediev (2011) pointed out the life span within the eastern European nations. The sudden change of financial conditions within the previous Eastern Piece nations that joined the European Union moderated down wellbeing weakening in those nations and expanded presentation terms to lower mortality levels. Concurring to Ediev (2011), this was expeditiously reflected by the meeting of these nations to the western European patterns.

\section{Data and methods}

Data for the variable GDP per capita were gained from UN National Accounts Main Aggregate database. The infant mortality rate data and life expectancy variable data were acquired from World Bank development indicators databases (World Bank, 2021).

Thus, in the research, as aggregate time series with annual data level were included: The GDP per capita in US\$ and infant mortality rate (as regressors) and life expectancy at birth (dependent variable). In order to examine the data at comparable level, the research was focused on regression model for the pooled cross-sectional time series with FIML method. Cross-section-specific time series are those that have values that differ between cross-sections. A set of these series are required to hold the data for a given variable, with each series corresponding to data for a specific cross-section (IHS Global Inc., 2019). Since cross-section-specific time series interact with cross-sections, they were defined in conjunction with the identifiers in pool object and there was applied estimation method that account for the pooled structure for the data. Having in mind that the aim was to estimate a complex specification that cannot easily be estimated using the built-in features of the pool object and that it is not available in pooled estimation, in these circumstances, the pool was used to create a system using both common and cross-section specific coefficients. After the parameters of a system of equations were estimated, the likelihood function under the assumption that the contemporaneous errors have a joint normal distribution was estimated as well. Provided that the likelihood function is correctly specified, FIML is fully efficient (IHS Global Inc., 2019). The resulting system using FIML method was further customized and estimated using all of the techniques available for system estimation. The restricted diagonal estimation was chosen to be set up zero restrictions on the off-diagonals of the residual covariance matrix. Only the diagonal elements of the residual covariance matrix that corresponded to the variances were estimated (IHS Global Inc., 2020). The life expectancy at birth function has two factors with five equations. Our full system can be written as in Eq. (1) and Eq. (2):

$$
Y Q+X B=E \quad \text { Assume }: E \mid X \sim N\left(0 \sum \otimes I_{T}-\text { An } M_{x}\right. \text { M matrix }
$$

This case can be characterized by defining the $M$ x $M$ matrix of contemporaneous correlations, $\Sigma$. $Y$ is the matrix of endogenous variables, $\mathrm{X}$ is the matrix of exogenous variables, $\Sigma$ is cross-equation covariance matrix of the error terms. In Eq. (1) above, $Q_{j}^{\prime}=\left(-1 \alpha_{j}^{\prime}, 0\right)$ and $B_{j}^{\prime}=\left(\beta_{j}^{\prime}, 0\right)$ (look for example, IHS Global Inc., 2019, p. 543). Furthermore, $\mathrm{I}_{\mathrm{T}}$ is identity matrix of order $\mathrm{T}$ and $\otimes$ denotes the Kronecker product (Balestra \& Varadharajan-Krishnakumar, 1987). The likelihood function can be written in the form as:

$$
L\left(B, Q, \sum \mid X\right)=(2 \pi)^{-T / 2}\left|\sum\right|^{-T / 2} \exp \left[\operatorname{tr}\left\{-1 / 2 E^{\prime} \sum E\right\}\right.
$$

Taking account of the normalization rule and the zero restrictions, a typical structural equation, say the jth one, can be written as:

$$
y_{i}=Y_{j} \alpha_{j}+X_{j} \beta_{j}+\mu_{j}=Z_{j} \delta_{j}+\mu_{j}
$$

Where, $\alpha$ and $\beta$ are the parameters to be estimated and where $Z_{j}=\left[X_{j} Y_{j}\right], \delta_{j}^{\prime}=\left[\alpha_{j} \beta_{j}\right]$. The system was estimated by full information maximum likelihood (FIML) method. Over the years, a number 
of approaches for FIML estimation have been proposed. In our case, the standard Broyden-FletcherGoldfarb-Shanno (BFGS) algorithm with the simple interpretation of Marquardt steps was used. The standard model that was used has been shown in Eq. (4):

$$
f=\left(y_{t}, x_{t}, \beta\right)=\epsilon_{t}
$$

Where $y_{t}$ is a vector of endogenous variables and $x_{t}$ is a vector of exogenous variables. The Full Information Maximum Likelihood (FIML) estimator finds the vector of parameters $\beta$ by maximizing the likelihood under the assumption that $\epsilon_{t}$ is a vector of i.i.d. multivariate normal random variables with covariance matrix $\Sigma$ (IHS Global Inc., 2020: 678).

Under the normality assumption, the log likelihood is given by:

$$
\log L^{*}=-\frac{T}{2} \log \left|\sum\right|+\sum_{t=1}^{T} \log \frac{\delta f_{t}}{\delta y_{t}^{\prime}}-\frac{1}{2} \sum_{t=1}^{T} f_{t}^{\prime} \sum f_{t}
$$

Where, $f_{t}=f\left(y_{t}, x_{t}, \beta\right)$. The log determinant of the derivatives of $\mathrm{f}_{\mathrm{t}}$ captures the simultaneity in the system of equations. For the unrestricted and diagonal restricted covariance variants of the model, the first-order conditions for the variance parameters was used and then the likelihood was rewritten in concentrated form:

$$
\log L=\sum_{t=1}^{T} \log \frac{\delta f_{t}}{\delta y_{t}}-\frac{T}{2} \log \left(T^{-1} \sum_{t=1}^{T} f_{t} f_{t}^{\prime}\right)
$$

The diagonal restricted estimator replaces the off diagonal terms in the latter matrix with zeros. The corresponding FIML estimator maximizes the concentrated likelihood with respect to the $\beta$ (or equivalently, the full likelihood with respect to $\beta$ and the free parameters of $\Sigma$ (IHS Global Inc., 2020: 679). The estimator for $\beta$ is asymptotically normally distributed with coefficient covariance which typically may be computed using the partitioned inverse of the outer-product of the gradient of the full likelihood or with the inverse of the negative of the concentrated likelihood.

\section{Main findings and discussions of the results}

Table 1 shows the estimated common coefficients and regression statistics for FIML.

\begin{tabular}{|c|c|c|c|c|}
\hline \multicolumn{5}{|c|}{ Estimation method: Full Information Maximum Likelihood } \\
\hline \multicolumn{5}{|c|}{ Dependent variable: life expectancy at birth } \\
\hline \multicolumn{5}{|c|}{ Sample: $2000-2020$} \\
\hline \multicolumn{5}{|c|}{ Included observation: 21} \\
\hline \multicolumn{5}{|c|}{ Total system (balanced) observation: 126} \\
\hline Independent variables & Coefficient & Std. error & t-statistics & Prob. \\
\hline GDP per capita & 0.0148 & 0.0154 & 2.748 & 0.0087 \\
\hline Infant mortality rate & -0.0324 & 0.0112 & -3.0024 & 0.0029 \\
\hline Intercept_Azerbaijan & 4.2625 & 0.0724 & 56.3418 & 0.0000 \\
\hline Intercept_Turkey & 4.2247 & 0.0685 & 62.2472 & 0.0000 \\
\hline Intercept_Georgia & 4.2831 & 0.0822 & 57.3542 & 0.0000 \\
\hline İntercept_Russia & 4.2562 & 0.0245 & 69.4571 & 0.0000 \\
\hline İntercept_İran & 4.2381 & 0.0591 & 61.3675 & 0.0000 \\
\hline Log likelihood & \multicolumn{4}{|c|}{-122.1989} \\
\hline Avg. log likelihood & \multicolumn{4}{|c|}{-0.8794} \\
\hline Akaike info criterion & \multicolumn{4}{|c|}{9.1682} \\
\hline Determinant residual covariance & \multicolumn{4}{|c|}{3.8463} \\
\hline Schwarz criterion & \multicolumn{4}{|c|}{9.5103} \\
\hline Hannan-Quinn criter. & \multicolumn{4}{|c|}{9.2867} \\
\hline
\end{tabular}

Table 1

Results of FIML method for Life expectancy at birth 
The results in Table 1 depict the framework estimation detail utilizing FIML strategy and give coefficients and standard error estimates, $z$-statistics, $p$ values, and summary statistics. From the results of the framework of condition estimation in Table 1, it can be seen that all of the coefficients are positive and statistically significant, except the coefficient of the newborn child mortality rate, which is additionally noteworthy but with negative sign. The residuals are picking up the effect of undetectable variables conjointly they are all positive and noteworthy at 5\% level. It implies that higher values of the GDP per capita and lower values of infant mortality levels lead to higher life expectancy at birth suggesting that the longevity of people in these five countries is increasing. These results are upheld by our speculations and theories. The newborn child mortality rate coefficient contains a negative sign and is subsequently thought to contribute fittingly to clarify the slant in life hope. The comes about appear that the life anticipation at birth is generally affected by the populace wellbeing and financial improvement within the nation: in other words, when populace wellbeing and financial improvement in a nation are getting way better, newborn child mortality rate is diminishing; appropriately, the life hope at birth shows up to have expanded. GDP per capita increments the life anticipation at birth through expanding financial development and improvement in a nation and in this way leads to the prolongation of life span. The signs of both the GDP per capita and newborn child mortality variable are steady with the inquire about speculations and affirm the contentions for the impacts of the financial advancement to life span.

1. The first major demographic process (postpartum) that affects the formation of the age-sex structure of the population is death. The general scheme of the impact of mortality on the overall age structure of the country's population in different age groups can be characterized as follows: The reduction of infant and child mortality plays an exceptional role in the rejuvenation of the age structure of the population. At the same time, the decrease in deaths among the able-bodied population leads to a decrease in the share of children and the elderly in the total population. The decrease in mortality in the upper age groups, especially at the age of 65 and older, leads to an increase in the share of this contingent in the overall structure, which leads to an aging population with all the socio-economic consequences of this process (www.stat.gov.az).

2. The main positive trends in the decline in mortality have led to an increase in life expectancy at birth. Thus, if the life expectancy at birth in Azerbaijan in 1970 was 70.9 years, including 66.8 years for men and 74.3 years for women, in 1990 this figure was 71.1 years, including 67 years for men. age, and 74.8 years in women. During 1990-1995, life expectancy in Azerbaijan as a whole was 69.1 years, including 65.2 years for men and 72.9 years for women. In the following periods, the dynamic development of the country's economy, as well as the rapid improvement of the social situation of the population had a positive impact on life expectancy, and in 2011 the life expectancy at birth was 73.8 years, including 71.8 years for men and 76 years for women. 5 years, and in 2012, the life expectancy at birth was 73.9 years, including 71.3 years for men and 76.6 years for women. The statistics for 2018-2019 allow us to say that the life expectancy at birth in Azerbaijan in these years was 75.8 years, including 73.3 years for men and 78.2 years for women (www.az.undp.org). The main reason for the different life expectancy at birth is the socio-economic development of the country. Thus, as a result of successful reforms implemented by the state in the socio-economic sphere, the main indicators of life expectancy at birth are also expressed in high figures.

The second factor that significantly affects the formation of the age-sex structure of the population is related to the level of population migration. As is known, as a result of the Nagorno-Karabakh war, which began in the 1990s, there was a mass exodus of refugees and internally displaced persons. At the same time, the lack of any level of material well-being of the population is one of the main factors accelerating population migration. If we take into account that a large part of population migration is the able-bodied population, then we can say that the acceleration of population migration leads to a decrease in the number of able-bodied people in proportion to this rate. From this point of view, by successfully implementing measures in the socio-economic sphere, the state is trying to reduce migration.

\section{Conclusions}

This paper analyzes the affiliation between socio-economic development and life expectancy at birth with both pay per capita and newborn child mortality rate as foundation factors for the financial advancement. Thusly, information from five, already understudied, EU promotion candidate nations from 2000-2020 have been utilized. A encourage oddity in a statistic setting is the utilization of the FIML strategy. Both coefficients of the foundation factors appear that the affect of a alter in wage per capita and newborn child mortality rate on life anticipation at birth have critical impacts. It appears that the life hope at birth is generally influenced by 
the populace wellbeing and financial improvement within the nation; in other words, when populace wellbeing and financial improvement in a nation are getting superior, newborn child mortality rate has diminished; in like manner, the life anticipation at birth shows up to have expanded. GDP per capita increments the life hope at birth through expanding financial development and advancement in a nation and in this way leads to the prolongation of life span. It can be concluded that the increment within the rate of GDP per capita as well as the decrease within the newborn child mortality rate has the same impact on the life anticipation in all five nations. Causality that runs one-way from life hope at birth to newborn child mortality rate was found.

The study found that there is a correlation between socio-economic development and mortality and life expectancy. Thus, the provision of the population with all services in the socio-economic sphere, especially health care, will ultimately lead to a decrease in the mortality rate and an increase in life expectancy.

\section{References:}

1. Andreev, E.M., Biryukov, V.A., Shaburov, K.J. (1994). Life expectancy in the Former USSR and mortality dynamics by cause of death: Regional aspects. European Journal of Population, no. 10, pp. 275-285 [in English].

2. Arland, T., Philipov, D. (2007). Developmental idealism and family and demographic change in Central and Eastern Europe. European Demographic Research Papers. Retrieved from: https://www.oeaw.ac.at/ fileadmin/subsites/Institute/VID/PDF/Publications/EDRP/edrp_2007_03.pdf [in English].

3. Balestra, P., Varadharajan-Krishnakumar, J. (1987). Full information estimations of a system of simultaneous equations with error component structure. Econometric Theory, vol. 3(2), pp. 223-246. DOI: https://doi.org/10.1017/S0266466600010318 [in English].

4. Birdsall, N. Kelley, A.C. Sinding, W.S., (2017). Population Matters: Demographic Change, Economic Growth, and Poverty in the Developing World. Oxford: Oxford University Press, 300 p. [in English].

5. Bloom, E.D. (2019). Population Growth, Structure, and Policy: Comment. Population Economics, Demographic Transition, and Development: Research and Policy Implications / ed. by A. Mason, T. Merrick, R. Paul Shaw. Washington, D.C.: World Bank [in English].

6. Bongaarts, J. (2009). Future Population Growth and Policy Options. Population Economics, Demographic Transition, and Development: Research and Policy Implications / ed. by A. Mason, T. Merrick, R.P. Shaw. Washington, D.C.: World Bank, pp. 55-65 [in English].

7. Ediev, D.M. (2011). Life Expectancy in developed countries is higher than conventionally estimated. Implications from improved measurement of human longevity. Population Ageing, no. 4, pp. 5-32. DOI: https://doi.org/10.1007/s12062-011-9040-x [in English].

8. IHS Global Inc. (2013). EViews 8 User's Guide II. Irvine: IHS Global Inc. [in English].

9. IHS Global Inc. (2017). EViews 10 User's Guide II. Irvine: IHS Markit [in English].

10. INED (2018). Births, deaths and infant mortality: Birth and death rates (per 1000 inhabitants) and infant mortality rate (per 1000 live births). Retrieved from: https://www.ined.fr/en/everything_about_population/ data/europe-developed-countries/birth-death-infant-mortality/ [in English].

11. Keifits, N. (2015). Some Demographic Properties of Transfers Schemes: How to Achieve Equity between the Generations. Economics of Changing Age Distribution in Developed Countries / R. Lee, W. Arthur, R. Rogers (eds.), 3rd ed. Oxford, pp. 102 [in English].

12. Mason, A., Lee, R. (2012). Demographic dividends and aging in lower-income countries. Retrieved from: https://www.ntaccounts.org/doc/repository/Mason_Lee_2012.pdf [in English].

13. Shkolnikov, V.M., Jdanov, D.A., Andreev, E.M., Vaupel, J.W. (2011). Steep increase in best-practice cohort life expectancy. Population and Development Review, vol. 37(3), pp. 419-434 [in English].

14. Shkolnikov, V., McKee, M., Leon, D.A. (2001). Changes in life expectancy in Russia in the mid1990s. The Lancet, no. 357, pp. 917-921 [in English].

15. Sickles, C.R., Taubman, P. (1997). Chapter 11: "The economics of fertility in developed countries". Handbook of Population and Family Economics / M.R. Rosenzweig, O. Stark (eds.). Amsterdam: Elsevier Science B.V., pp. 561-643 [in English].

16. UN (2021).United Nations Statistical Division - National Accounts main aggregate database: Retrieved from: https://unstats.un.org/ [in English].

17. World Bank (2021).World Bank Open Data, free and open access to global development data, indicators, Retrieved from: http://data.worldbank.org/indicator [in English].

18. Zaman, S., Hossain, N., Mehta, V., Sharmin, S., Mahmood, S. (2017). An Association of Total Health Expenditure with GDP and Life Expectancy. Journal of Medical Research And Innovation, vol. 1(2), pp. AU7AU12. DOI: https://doi.org/10.5281/zenodo.576546 [in English]. 
19. State Statistical Committee of the Republic of Azerbaijan. Retrieved from: www.stat.gov.az (24.02.2021) [in Azeri].

20. UNDP. Retrieved from: www.az.undp.org (24.02.2021) [in English].

\title{
АНАЛІЗ ЗВ'ЯЗКУ МІЖ РІВНЕМ СОЦІАЛЬНО-ЕКОНОМІЧНОГО РОЗВИТКУ, СМЕРТНІСТЮ ТА ТРИВАЛІСТЮ ЖИТТЯ
}

\author{
Сабіна ДЖУМАЗАДЕ, \\ аспірант \\ Інституту економіки Національної академії наук Азербайджану, \\ викладач кафедри менеджменту \\ Азербайджанського університету туризму та менеджменту \\ sebine.yusifova52@gmail.com \\ orcid.org/0000-0001-5962-7674
}

Основна мета дослідження - оцінити зв 'язок між рівнем соціально-економічного розвитку та показниками смертності й тривалості життя. Для досягнення иієї мети встановлено основні чинники, щзо впливають на статево-вікову структуру населення, та визначено механізм впливу ичих чинників на смертність $i$ тривалість життя.

Метод і методологія дослідження. У роботі використані порівняльний аналіз, логіко-системний підхід, порівняння та узагальнення, аналіз і синтез, економіко-статистичні методи.

Наукова новизна дослідження заснована на взаємозв'язку рівня соціально-економічного розвитку зі смертністю та тривалістю життя. Також встановлені фактори, щзо визначають статево-вікову структуру населення, механізми народжуваності й смертності, міграиію.

Результати. У процесі дослідження аналізували взаємозв'язок рівня соціально-економічного розвитку та народжуваності й очікуваної тривалості життя на основі статистичних даних Азербайджану, Туреччини, Грузії, Росї та Ірану з використанням стратегї FIML. У результаті дослідження встановлено, щзо статево-вікова структура населення формується внаслідок тривалих історичних змін рівнів народжуваності, смертності та міграції, а також еволюиії ичих процесів. Результати свідчать про те, щзо кожен із факторів, наприклад народжуваність і смертність, тією чи іншою мірою впливає на статевовікову структуру населення.

Висновки. Результати дослідження вказують на зв'язок між соціально-економічним розвитком та смертністю і тривалістю життя. Таким чином, повноцінне забезпечення населення всіма послугами в соціальній сфері, зокрема й охорона здоров'я, у підсумку впливає на зниження смертності та збільшує тривалість життя. Водночас зростання ВВП на душу населення сприяє зниженню материнської смертності та збільшенню тривалості життя, щзо забезпечує матеріальне благополуччя населення.

Ключові слова: соціально-економічний розвиток, людський розвиток, економічне зростання, розвиток здоров'я, рівень життя, тривалість життя. 